Portland State University

PDXScholar

Political Science Faculty Publications and

Presentations

Political Science

7-1-2017

\title{
Caring, Killing, Euphemism and George Orwell: How Language Choice Undercuts Our Mission
}

David Johns

Portland State University, johnsd@pdx.edu

Dominick A. DellaSala

GEOS Institute

Follow this and additional works at: https://pdxscholar.library.pdx.edu/polisci_fac

Part of the Social and Behavioral Sciences Commons

Let us know how access to this document benefits you.

Citation Details

Johns, David and DellaSala, Dominick A., "Caring, Killing, Euphemism and George Orwell: How Language Choice Undercuts Our Mission" (2017). Political Science Faculty Publications and Presentations. 61. https://pdxscholar.library.pdx.edu/polisci_fac/61

This Post-Print is brought to you for free and open access. It has been accepted for inclusion in Political Science Faculty Publications and Presentations by an authorized administrator of PDXScholar. Please contact us if we can make this document more accessible: pdxscholar@pdx.edu. 


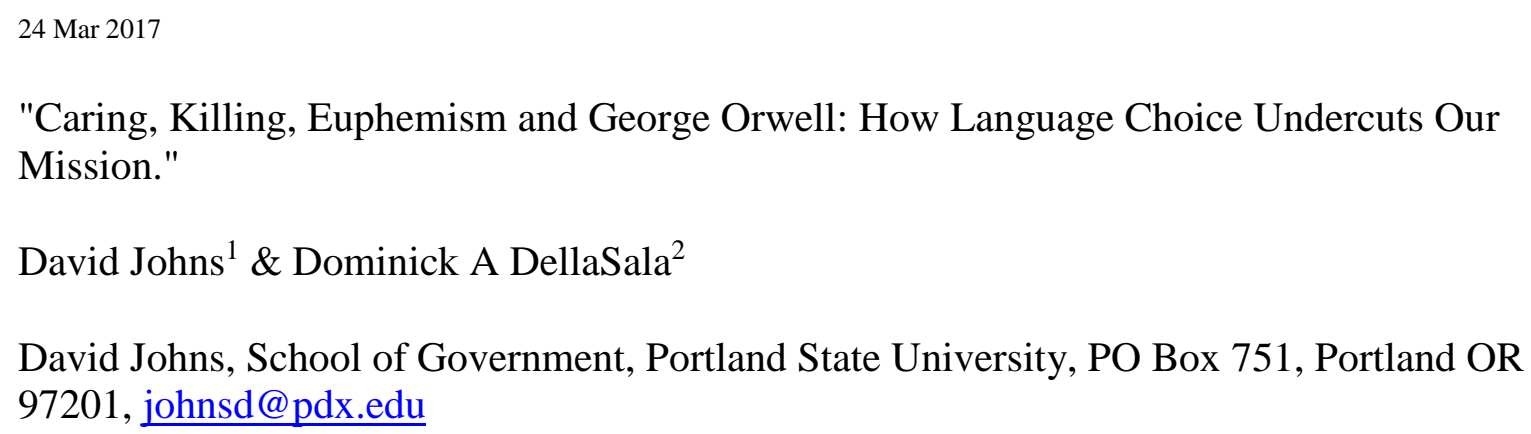

15 What does George Orwell have to do with Conservation Biology? As one of the foremost critics

16 of how language is used, he has quite a lot to say. He was not just a critic of the imprecise or the

17 dreary, but of the power of language to mislead; he understood the power of language to evoke

18 the passion of a mission-value-morality driven discipline such as conservation biology, or drown

19 it in what he called orthodoxy — a condition that "seems to demand a lifeless, imitative style."

20 (Orwell 1964:IV: 135) Too often, he noted, speech about values was "the defense of the

21 indefensible." (Orwell 1964: IV: 136) We argue in this essay that euphemism is a means to mask

22 the indefensible and conservation biologists should not be a party to that.

24 Most papers presented at conservation biology meetings and published in our journals have to do

25 with understanding how biodiversity is impacted by human activities. Less often we consider our

26 purposes, values and motivation. But these aspects of our work are equally important; they

27 address why we do what we do, and the purpose of what we do.

29 For example, according to its mission statement, the Society for Conservation Biology “...

30 advances the science and practice of conserving Earth's biological diversity(;)" and "envisions a 
31 world where people understand, value, and conserve the diversity of life on Earth." (italics

32 added)

34 To achieve the vision and fulfill the mission depends on motivating others to care and to act on

35 behalf of biodiversity. In turn that means being clear about our moral purpose:

Biodiversity is good (Soulé 1985)

38 Science is not enough to resolve the extinction and climate crises we are in. Moreover science

39 does not require we be passionless or meek — only that we be honest, do not distort our findings

40 or otherwise try to make them conform to desired outcomes. Being unbiased does not require

41 lack of caring; indeed, to not care is to be alienated.

43 We argue that the widespread use of euphemisms by many conservation biologists, conservation

44 journals, and conservation biology course materials undermines our effort to evoke caring in

45 others for life on Earth and even to care for ourselves.

47 A euphemism is "The act or example of substituting a mild, indirect, or vague term for a

51 In more words the Oxford English Dictionary says the same thing. 
"That figure of speech which consists in the substitution of a word or expression of comparatively favorable or less unpleasant associations instead of the harsher or more offensive one that would more precisely designate what is intended." (Compact OED 1971, I: 903).

58 Euphemisms, then, use language choice to describe activities in acceptable words that audiences

59 would otherwise find objectionable. Euphemisms mislead by candy coating reality. They sanitize 60 and disguise, and are not neutral terms. As one example, "we harvested a sample of 100 fish for 61 analysis of stomach contents", rather than "we caught and killed 100 fish for analysis of stomach 62 contents."

64 Other words can mislead for different reasons, including metaphors — a "figure of speech in 65 which a name or descriptive term is transferred to some object different from, but analogous to, 66 that to which is properly applicable" (Compact OED 1971, I: 1781). For example, using 67 economic metaphors to describe the natural world—natural assets, stocks, maximum sustainable 68 yield, forest harvest, natural capital and debt — is reductionist: it suggests the natural world is part 69 of the human economy rather than the other way around and that the former operates like the 70 lateral in a literal and mechanistic way; it also strongly implies that only those aspects of the 71 larger world that have economic value have value (Coffey 2016).

73 Metaphors can also create strong, vivid images that impart insight via their analogies. But 74 analogies are just that — not meant to be literal, wholly accurate terms. In contrast euphemisms 75 purport to be accurate descriptions when in fact they misrepresent it. Both may mislead-some 
76 metaphors may be bad metaphors, i.e. not good analogies. But all euphemism, intent aside, candy

77 coat and undercut caring by creating emotional distance from that which conservationists seek to

78 evoke caring. A metaphor might undercut caring but if so it is more likely because of the

79 listener's error in taking it literally rather than rejecting it as a bad analogy. For example, the

80 metaphor "forest health" alludes to actions taken to maintain the function of a forest much like

81 actions may be taken to maintain human function in the face of disease. Cutting old growth trees,

82 however, is a bad analogy with treating disease.

84 Similarly, language that is vague and unnecessarily abstract can be problematic — so-called

85 buzzwords, which appear to offer easy insight and information and in the course of that become

86 commonly used. "Sustainability" or "sustainable" are widely used, including in policy

87 statements, but they are rarely defined. Just what is proposed to be sustained? Human societies?

88 The human species? Or ecological systems and their full complement of species? The difference

89 is significant - one species or all species. And the course of action necessary for the latter is

90 quite different than the former.

91

92 Students of story recognize that they are useful to humans because they simplify reality and

93 thereby help make life manageable. But what about when understanding is the goal, as with

94 science? Goldstein (1999) argues that scientists too often fall victim to the temptation to simplify

95 in the face of the tremendous complexity of the biological world. They seek shortcuts

96 understanding the natural world, the damage done to it by humans, and in figuring out ways to

97 heal it. The results include abstractions which represent vaguely defined processes or properties

98 of systems that lack empirical validity and cannot be substituted for life history of populations 
99 and therefore result in recommendations that usually cannot help real organisms. He argues, for

100 instance, that "ecosystem management" is too broad to be evaluated (1999: 249) — ecosystems

101 are dynamic and goals such as maintaining predation (our example) mean little apart from

102 understanding specific native predator populations. David Ehrenfeld (1979) and others raise

103 important related questions, such as whether humans are capable of understanding let alone

104 managing such complexity. Buzzwords gloss over these questions and give false impressions of

105 precision and are misleading if also the product of good faith efforts at problem solving.

107 How do we know if a word or phrase is a euphemism? Here's a self-test. Apply the term or

108 phrase to some entity or group you care about and gauge your reaction. If you are uncomfortable

109 it is probably a euphemism. If it makes you feel dishonest it almost certainly is a euphemism.

110 Would you "sacrifice" or "cull" those you care about so that some knowledge might be gained?

112 Beyond a self-test, ask if the words or phrase convey an accurate description of what is

113 happening, or obscure it; does it preclude a negative emotional response to an activity through

114 use of vague and pleasant words. We are all familiar with the common use of euphemisms in

115 human politics — terms such as “collateral damage," which aims to soften our reaction to killing

116 of civilians in the course of military action. The term "bycatch" is similar, referring to the

117 (foreseeable) killing of non-targeted wildlife during efforts to capture and kill commercial

118 species. "Bycatch" may be as high as $40 \%$ by weight of all life killed (Davies et al 2009). Why

119 don't biologists use a more straightforward description? 
121 "Harvest" is common and in wide use in conservation biology as well among those who study

122 forests, fish and wildlife with a goal to maximizing exploitation and economic benefits. And it

123 illustrates the history of the adoption of this and similar terms in conservation. Harvest is an

124 ancient term and generally refers to "gathering in a crop," usually of grains, fruits, or vegetables

125 planted or tended deliberately as human food. "Wildlife managers" in the $20^{\text {th }}$ Century borrowed

126 the term from agriculture (Leopold 1986 [1933]: 3-4), ironically the principal threat to wildlife

127 and wild places for the last 12 millennia.

128

129 Although Leopold later changed his thinking on this topic his initial conceptualization regarded

130 wildlife management as producing crops of wild game, while maintaining maximum yield via

131 human interventions in the landscape-interventions which included targeting other species such

132 as predators to maintain the yield of these desired species. Several of these agricultural terms

133 seeped into various biology disciplines before his understanding changed.

135 "Harvest" is used to describe killing part or all of the individuals of a wild species for food,

136 because a species is inconvenient to some humans, for fun, or because humans have degraded

137 habitat and ecosystems are "out of balance" and need to be righted. Interestingly the killing of

138 domestic animals for food and sometimes other purposes is referred to as slaughter, a harsher

139 term. Even "killing" can obscure the grim details: poisoning, shooting, leg-hold trapping,

140 snaring, drowning, suffocating, chasing down with machines.

141

142 Harvest preempts acknowledgement of qualities that may be possessed by those being killed:

143 Sentience 
Place in social structure

Fear

149 Harvest does not evoke caring and empathy, outrage at loss of life, but instead distances and 150 objectifies.

151 It does not evoke the moral purpose of conservation but wildlife as crops owned by humans. It 152 implies the human right to inflict injury and even impose death to balance the "books" we have

153 brought disorder to. It conveys the idea that the killing is orderly process intended to benefit 154 people and that such benefit is presumptively justified; it may also presume that the species 155 being killed benefits along with the ecosystem of which it is a part.

157 Wild plants are also subject to the term harvest. It is sometimes used to describe the destruction 158 of complex living systems called forests and their replacement by tree farms, domesticated 159 monocultures, or subdivisions.

161 There are many other euphemisms that attempt to sanitize human violence toward the natural 162 world:

164 "Collect" is to kill for the sake of human knowledge without considering the knowledge lost by 165 killing. Sometime sacrifice is used as if we were priests. 
167 "Working lands" is one our favorites, calling to mind the laziness of Wilderness. In facts the

168 lands referred to as working are domesticated, usually degraded. A common example is

169 rangelands heavily grazed by cattle, sheep and other domestic animal. In fact such lands are

170 occupied lands, with human activities displacing other species. In many countries, such

171 rangelands often receive massive public subsidies in terms of tax benefits, road construction, and

172 energy use.

173

174 "Fire destroys, blackens..." ignores the essential role of fire in many systems and the serious

175 and lasting damage of fire suppression. Using the term "fuels" instead of "dead wood" in a fire-

176 adapted forest tends to distance foresters from seeing vegetation and its important role in such

177 forests. It allows foresters to ignore their own role in creating an ecosystem prone to massive 178 fires.

179

180 "Silvicultural treatment..." usually includes the application of toxic chemicals that poison soil

181 and water, or the use of heavy equipment that compacts or otherwise disturbs soils.

182

183 The conceptual grandparent of so many euphemisms might be "natural resources." It reduces all

184 the world to narrow utilitarian human uses. One of us (DD) has a $\mathrm{PhD}$ in "Natural Resources"

185 from the School of Natural Resources, University of Michigan.

186

187 Tag, administrative removal, incidental "take" and others come to mind. 
190 These terms disconnect us from the consequences of our actions. They diminish or preclude

191 emotion. Yet it is emotion that connects us to each other, to other creatures, to the wider world

192 that made us. Without emotion we would be hollow and lonely indeed. We would not be

193 conservationists.

195 One more term deserves mention in this brief survey: cull.

197 Cull is a term that can obscure the cause of conservation problems. US agencies have killed, are

198 killing and plan to kill sea lions and cormorants in the Columbia River because they eat salmon

199 that are endangered. Indeed they are, but why? Because of dams, water temperature increases in

200 streams, logging, grazing, and road-building. Not because of sea lions and cormorants.

202 The term cull makes the destruction of the largest double-crested cormorant colony in the 203 world — at the mouth of the Columbia River — seem a difficult necessity rather than a case of 204 scapegoating that rationalized the violent destruction of life. By invoking the implication of 205 unfortunate necessity, the real, human causes of salmon decline are off the table: massive hydro 206 dams, logging which destroys spawning streams, grazing, and pollution. The difficult problem of 207 changing human behavior, including weaning us from cheap energy (because the costs are 208 externalized), do not have to be dealt with.

209

210 What are conservation biologists to do? We have an obligation to: 
213 values - not to make people comfortable.

214 Explore more accurate language for how plants and animals are treated by

215 humans, including ourselves.

$216 \quad$ Use language that evokes our moral purpose.

218 Euphemism is not part of the solution, it is part of the problem. It is up to all of us to invent a 219 new and better language. Maybe a simple place to start is to give animals names. Cecil the lion 220 had a name and it generated an important discussion about the value of life. .

$224 \underline{\text { Citations }}$

226 American Heritage Dictionary, The. 1993. $3^{\text {rd }}$ Ed. Houghton Mifflin. Boston, MA

228 Coffey, Brian. 2016. "Unpacking the Politics of Natural Capital and Economic Metaphors in 229 Environmental Policy Discourse.” 25 Environmental Politics 2: 203-222.

231 Davies, R., Cripps, S., Nickson, A., and Porter, G. 2009. Defining and estimating global marine 232 fisheries bycatch. Marine Policy, doi:10.1016/ j.marpol.2009.01.003.

234 Ehhrenfield, David. 1979. Arrogance of Humanism. Oxford UP. New York. 
236 Goldstein, Paul Z. 1999. "Functional Ecosystems and Biodiversity Buzzwords.” 13 Conservation 237 Biology 2: 247-255.

238

239 Leopold, Aldo. 1986 (1933). Game Management. University of Wisconsin Press. Madison WI.

241 Oxford English Dictionary, Compact. 1971. (2 vol.) Oxford University Press. New YorkCity.

243 Society for Conservation Biology. 2016. Strategic Plan 2016-2020.

244 http://conbio.org/images/content_about_scb/SCB_Strategic_Plan_2016-2020_Final.pdf

245 (accessed 7 Oct 2016).

246

247 Soulé, Michael. 1985. "What is Conservation Biology?” 35 BioScience 11: 727-734. (Soulé

248 freely admits plagiarizing from Genesis 1: 12, 21 and 25.)

249

250 